\title{
Dietary Behavior Change In Surabaya University's Male Workers With Dietary Behavior Education
}

\author{
Dewi Susanti Atmaja $a^{1 * \dagger}$ \\ ${ }^{1}$ Faculty of Pharmacy Surabaya University Indonesia \\ ${ }^{\dagger}$ Current Correspondence: Pharmacy Department of Sari Mulia School of Health Sciences, \\ Banjarmasin Indonesia \\ *dewi.s.atmaja@gmail.com
}

\author{
Abdul Rahem ${ }^{2}$ \\ ${ }^{2}$ Faculty of Pharmacy Airlangga Univesity Indonesia \\ rahem_yakersuda@yahoo.co.id
}
Lisa Aditama ${ }^{1}$
${ }^{1}$ Faculty of Pharmacy Surabaya University Indonesia lisa_aditama@ubaya.ac.id

Franciscus Cahyo Kristianto ${ }^{1}$

${ }^{1}$ Faculty of Pharmacy Surabaya University Indonesia fckristianto@gmail.com

\begin{abstract}
Objective : This research aims to see the relation between diet behavior education to change of obesity patients dietary behavior.

Method : This research design is quantitative with a before-after method to test the effect of giving proper dietary behavior to change in the diet behavior of obesity patients. The subjects of this research are 28 male workers of Surabaya University with obesity level I. Subject will receive the intervention, which is 12 diet behavior education meeting (once a week). Variable that will be measured is diet behavior change based on calorie consumption and food consumption classification based on Health Diet Indicator (HDI) and also a measurement of Body Mass Index (BMI) and subject's abdominal circumference. All measurements are done before and after the intervention.

Results : Statistic test uses paired test $t$ with Confidence Interval (CI) value $=95 \%$ shows the result of $\mathrm{p}$ for $\mathrm{HDI}=0.774$, calories $=0.000, \mathrm{BMI}=0.000$ and waist circumference $=0.000$. The result of $\mathrm{p}$ shows that there is no significant change for HDI, while calories consumption, BMI and waist circumference of research subjects have a significant change. Average calories consumption of research subjects are decreased around $302.571 \mathrm{kcal} /$ day, average BMI reduction is $0.968 \mathrm{~kg} / / \mathrm{m}^{2}$ and average waist circumference reduction is around $7.446 \mathrm{~cm}$. Value $\mathrm{r}$ for calories consumption reduction $=0.436$, waist circumference reduction $=0.693$ and research subjects BMI reduction $=$ 0.887 .
\end{abstract}

Conclusion : Dietary behavior education provides a change in calories consumption of obesity patients, BMI, and abdominal circumference.

Keywords : Abdominal circumference, BMI, Diet behavior, Education, Obesity 


\section{INTRODUCTION}

The increased body mass index (BMI) and abdominal circumference should be worried by all people around the world because it can cause greater risk factor to health problems. The investigation is done by National Institutes of Health at the year 2002 using 14.924 participants that have BMI and abdominal circumference at normal category to high category shows that there is a prevalence increase for hypertension disease, diabetes mellitus type 2 , hypercholesterolemia and metabolic syndrome for participants with higher BMI and larger abdominal circumference [1]. The individual has high BMI is classified as an overweight category and obesity level 1 . Overweight and obesity in adults in the past is defined as an overweight $20 \%$ more than ideal body weight which is a product of a disorder of body composition in the form of fat. According to World Health Organization (WHO) in adults, overweight is defined by BMI $\geq 25,0 \mathrm{~kg} / \mathrm{m}^{2}$, obesity is defined by BMI $\geq 30,0 \mathrm{~kg} / \mathrm{m}^{2}$. Overweight for Asia people are defined by BMI $23,0 \mathrm{~kg} / \mathrm{m}^{2}$, and obesity is defined by $\mathrm{BMI} \geq 25,0 \mathrm{~kg} / \mathrm{m}^{2}[2,3]$.

Obesity is not only measured by BMI but it can be done by measuring the abdominal circumference. Abdominal circumference is classified as obesity in adult according to WHO is $\geq 94 \mathrm{~cm}$ for male dan $\geq$ $80 \mathrm{~cm}$ for female. The standard for Asia people is not the same as WHO's standard, for Asia people abdominal circumference that is classified as obesity is $\geq 90 \mathrm{~cm}$ for male and $\geq 80 \mathrm{~cm}$ for female. A person with obesity category abdominal circumference has a higher risk for other health problems than a person with the normal abdominal circumference. Obesity is usually categorized as a pathologic condition because this condition can raise death risk from hypertension, dyslipidemia, diabetes mellitus type 2, coroner heart disease, stroke, gallbladder disease, osteoarthritis, sleep problem, reproduction system problem and colon cancer $[4,5]$.

Obesity is usually caused by cumulative energy consumption is bigger than needed in daily activity. This excess energy is kept in form of fat, carbohydrate or protein, this can cause fat tissue enlargement. Enlarge fat tissue affects adverse health conditions, this depends on fat masses and the location of the fat tissue. Fat masses affects body shape change and reaction that is being produced by the body (for example osteoarthritis and sleep apnea). The location of fat tissue affects adverse metabolic for the body when the fat tissue enlarges. Increased intra-abdominal or visceral fat can cause a serious problem for health. Production of adiponectin, inflammation marker, vascular factor and leptin of enlarge visceral fat tissue cause metabolic problem like diabetes, dyslipidemia atherogenic (decrease of HDL level and increase of triglyceride) and release of inflammation marker like interleukin - 6 (IL6) and tumor necrosis factor (TNF - $\alpha$ ) or 
coagulant factor like plasminogen activator inhibitor - $1(\mathrm{PAI}-1)[6,7,8]$.

Overweight and obesity patients usually have cardiovascular risk factor like hypertension, high LDL cholesterol $(\geq 160$ $\mathrm{mg} / \mathrm{dL})$, low HDL cholesterol (<35 mg/dL), abnormal fasting glucose $(110-125 \mathrm{mg} / \mathrm{dL})$. Risk factor control for overweight and obesity patients usually begins with body weight reduction therapy. Reduced body weight can help to reduce the risk factor for cardiovascular diseases. Body weight's increment in adults is usually caused by a transition from active lifestyle during teenage age and early 20s to sedentary lifestyle meaning lifestyle that involves more sitting activity and less standing and walking activity also doesn't involve lifting weight $>5 \mathrm{~kg}$ in daily activity. Body weight's increment continues for years at the adult age to 60s. And at 55-64 years old, body weight is relatively stable and then lowers $[9,10]$.

Food factor and physical lifestyle are considered as main modification factor contributing to the overweight problem if those factors are intervened then that can be used to prevent obesity. Precaution and obesity management must be focused on social factor and the environment that affects high or low people status in general, process and program to manage people and social groups have a high risk for obesity. Intervention aims for precaution and obesity management must be designed to prevent the developing problem from an irrational fear of getting fat and able to prevent unhealthy behavior like smoking that patients believe can prevent body weight gain. Obesity management must be evaluated correctly, including diet management, physical activity, lifestyle modification, drug therapy and gastric surgery. Simple energy deficiency diet is more effective and can be accepted that large energy deficiency to reach and stabilize body weight. The efficiency of diet therapy is increased if physical activity and lifestyle modification are included in management planned for each individual. More evaluation of lifestyle modification strategy and combined therapy right now are needed to gain body weight reduction for long-term [10].

Diet intervention for reducing body weight must include food choice modification, number, and frequency of food and drink consumption. To reduce body weight by $0,5 \mathrm{~kg}$ each week needs calories reduction around $3500 \mathrm{kcal}$ each week or 500 kcal each day. Randomized control trial research in short-term which gives diet intervention needed for optimal diet identification to obesity therapy (which are body weight reduction, stabilize body weight and comorbidity management). NICE Guidelines in 2006, comparing various diet intervention in overweight and obesity patients with duration of giving the intervention in 12 months. Reducing calories consumption around $600 \mathrm{kcal}$ each day can reduce body weight around $0,6 \mathrm{~kg}$ each week. 
Other than that, clinical benefit is also seen to prevent diabetes and hypertension disease. This effect can last until 3 years [11]. This research aims to see whether there is or isn't direct effect of diet behavior management education to dietary behavior change in obesity patients.

\section{METHOD AND PROCEDURE}

Research design includes experimental study, using before-after study design, do variables measurement system before and after the intervention. Research is done by quantitative to see a change in diet behavior for obese male workers in Surabaya University with diet behavior education. The sample that is used in this research is male workers in Surabaya University having obese level 1(BMI 25-29,9 $\mathrm{kg} / \mathrm{m}^{2}$, abdominal circumference $\geq 90 \mathrm{~cm}$ ) and willing to participate diet behavior education program for obesity patients and fill the informed consent form. The sample is obtained by using convenience sampling method.

Intervention given to research subjects is face to face education and SMS(Short Message Service) each week step by step with the purpose to remind the research subjects of doing diet behavior change. The content of SMS is to remind subjects to do change in diet behavior which is a healthy diet. Subjects of this research will receive a healthy plate for their guide to healthy diet consumption and agenda book for self-recording media.
Variables that will be examined in this research include a change in obesity patient's behavior in diet evaluated from calories consumption and food classification based on Healthy Diet Indicator (HDI) and also BMI changes and abdominal circumference of the research subject. This research data gathering is done by taking baseline check-list data before intervention, data which is self recording format related to diet is taken a week before and after intervention, direct interview data by nutritionist is taken each 2 points ( 2 different times in a week) before and after intervention, body weight measurement and abdominal circumference data are taken before and after intervention.

Data are obtained from this research will be analyzed using SPSS version 21 in Macintosh. The analysis aims to describe the significant relationship between providing diet management education to dietary behavior change in obesity patients, BMI, and abdominal circumference change.

\section{RESULTS}

This research is done at Surabaya University during March to June 2017

\section{Table 1. Demography dan Subject}

\section{Characteristic}

\begin{tabular}{|c|c|}
\hline Demography & Subject $(n=28)$ \\
\hline Age $($ mean \pm SD $)$ & $42,57 \pm 4,94$ year \\
\hline Level of education & \\
\hline $\begin{array}{l}\text { a. Do not finish high } \\
\text { school }\end{array}$ & $1(3,57 \%)$ \\
\hline b. High school & $14(50,00 \%)$ \\
\hline c. Bachelor's degree & $11(39,29 \%)$ \\
\hline $\begin{array}{l}\text { d. Master's degree, } \\
\text { Doctoral degree, and } \\
\text { Professor }\end{array}$ & $2(7,14 \%)$ \\
\hline
\end{tabular}


Result of validity and reliability test of questionnaires in this research scores $\alpha>0,7$ and $r>0,3$ [12]. Subject's diet behavior profile is evaluated based on diary selfrecording which is written by subject and interview result done by a nutritionist.

Table 2. Univariate Analysis

\begin{tabular}{|c|c|c|c|c|}
\hline Variabel & Min & Max & Mean & St Dev \\
\hline \multicolumn{5}{|c|}{ Before Intervention } \\
\hline HDI & 2.00 & 4.00 & 3.00 & 0.72 \\
\hline $\begin{array}{l}\text { Calorie } \\
\text { (kcal/day) }\end{array}$ & 662.10 & 2173.50 & 1359.42 & 417.52 \\
\hline BMI $\left(\mathrm{kg} / \mathrm{m}^{2}\right)$ & 25.22 & 29.69 & 26.99 & 1.21 \\
\hline $\begin{array}{l}\text { Abdominal } \\
\text { circumference } \\
(\mathrm{cm})\end{array}$ & 90.00 & 102.00 & 95.02 & 3.08 \\
\hline \multicolumn{5}{|c|}{ After Intervention } \\
\hline HDI & 1.00 & 4.00 & 2.93 & 0.94 \\
\hline $\begin{array}{l}\text { Calorie } \\
\text { (kcal/day) }\end{array}$ & 531.80 & 1780.40 & 1056.85 & 300.18 \\
\hline BMI $\left(\mathrm{kg} / \mathrm{m}^{2}\right)$ & 24.24 & 28.96 & 26.02 & 1.06 \\
\hline $\begin{array}{l}\text { Abdominal } \\
\text { circumference } \\
(\mathrm{cm})\end{array}$ & 81.00 & 95.00 & 87.57 & 4.02 \\
\hline
\end{tabular}

Before the intervention, the average score of subject's HDI is around $3.00 \pm 0.72$ and after the intervention, the average score of subject's HDI reduces to $2.93 \pm 0.94$. HDI has 3 categories as follows: low $(<3)$, medium (3-4) and high (>4). Higher HDI scores someone has, it shows good health food consumption. For this research, there is no subject who has high HDI. Each calories consumption of research subjects before intervention is a $1359.42 \pm 417.52 \mathrm{kcal} /$ day and after the intervention, average calories consumption reduces to $1056.85 \pm 300.18$ $\mathrm{kcal} / \mathrm{day}$. The average BMI score subjects have before intervention is $26.9999 \pm 1.21$ $\mathrm{kg} / \mathrm{m}^{2}$ and after the intervention, it reduces to $26.02 \pm 1.06 \mathrm{~kg} / \mathrm{m}^{2}$. Before the intervention, the average abdominal circumference of research subjects is $95.02 \pm 3.08 \mathrm{~cm}$ and after the intervention, it becomes $87.57 \pm 4.02 \mathrm{~cm}$.

Table 3. Bivariate Analysis

\begin{tabular}{lccc}
\hline \multicolumn{1}{c}{ Variabel } & r & p value & Mean rank \\
\hline HDI & -0.219 & 0.774 & 0.071 \\
Calorie & 0.436 & 0.000 & 302.571 \\
BMI & 0.887 & 0.000 & 0.968 \\
$\begin{array}{l}\text { Abdominal } \\
\text { circumference }\end{array}$ & 0.693 & 0.000 & 7.446 \\
\hline
\end{tabular}

Statistical test using test $\mathrm{t}$ is pairing with Confidence Interval (CI) score $=95 \%$ shows the result of score $\mathrm{p}$ for HDI $=0.774$, calories $=0.000, \mathrm{BMI}=0.000$ and abdominal circumference $=0.000$. The result of $p$-value shows that for HDI, there is no significant change, while calories consumption, DMI and abdominal circumference of research subjects have a significant change. Average calories consumption of research subjects has reduction around $302.571 \mathrm{kcal} / \mathrm{day}$, average BMI reduction is around $0.968 \mathrm{~kg} / \mathrm{m}^{2}$ and an average of abdominal circumference reduction is around $7.446 \mathrm{~cm}$.

Giving diet behavior management to research subjects has a direct relation with reduction of calories consumption, BMI and abdominal circumference of research subjects. Value $\mathrm{r}$ for reduction of calories consumed is around 0.436 , this shows how giving diet behavior management education has a strong relationship with the reduction of abdominal circumference of research subjects. And diet management education has a strong relationship with the reduction of research subjects' BMI based on value $r=0.887$. 


\section{DISCUSSION}

This research aims to see whether there is or isn't direct effect of diet behavior management education to dietary behavior change in obesity patients. Obesity causes a lot of high-risk factors which are dangerous for health and can be developed to chronic diseases. The treatment of this condition can be done by giving proper diet management education which is one of the therapeutic approaches for obesity patients. A healthy diet can help to reduce BMI and abdominal circumference, so it is expected to help to reduce the risk factor for diseases caused by obesity. This research uses obese male workers of Surabaya University Banjarmasin which are given diet management education.

An intervention that is given to research subjects is face to face education for 12 times (once a week) and sending SMS to make sure research subjects doing diet behavior change which is a healthy diet. Research subjects also receive healthy plate and diary which function as education guide and self-recording media. The healthy plate will be always used by research subjects when eating and diary book is used to record what foods the research subjects eat. Subject diet profile is obtained based on self-recording done by the subject and interview by a nutritionist. The subject didn't know when the interview will be conducted, this is done because the subject doesn't have prepared for what food the subject eat before the interview so the researcher can get data based on subject daily consumption. Before education, average calories consumption is around $1359.42 \pm 417,52 \mathrm{kcal} /$ day and after education, average calories consumption reduces to $1056.85 \pm 300.18 \mathrm{kcal} /$ day [13]

Behavior profile of subject diet can be reviewed based on increase Healthy Diet Indicator (HDI) classification which is obtained from the recording of a selfrecording diary by subject and interview by a nutritionist. There are 7 persons have to increase HDI classification after giving education to their spouse, but there is no subject having high HDI classification. Reduction of HDI classification also happens in 7 persons after each of their spouses are given education. Unable to get high HDI classification and reduction of HDI score in several subjects because of lack and high price of healthy food so the majority of subjects consume foods that are not compatible with HDI.

Working environment also contributes because some of the subjects complain available foods at working place are not compatible with diet suggested by the researcher. This becomes a hindrance which subjects experience for doing healthy diet and this is also the main reason why they can't use the healthy plate in working place. Aside environment factor, some subjects also don't bring food from home, because lack of support from spouse provided by a spouse in terms of preparation of supplies and motivation. 
Diet management education has relation to reduction calories consumption, BMI, and abdominal circumference, but doesn't have relation with HDI because research subjects were having a hard time to get foods which are compatible with HDI criteria. Lack of support from spouses is noticed from no supply of food are prepared for research subjects, causes diet management can't have a maximal result. It is better to give diet management education not just for research subjects but also for their spouse so we can have better diet behavior change.

\section{CONCLUSION}

Dietary behavior education effect on decreased calorie intake, BMI, and abdominal circumference but not on HDI. This is because the lack of the role of the family in preparing healthy food. To improve the success of dietary behavior is required also support from the family especially in the preparation of healthy food. Indeed, education is not only given to people with obesity but also given to the family.

\section{REFERENCES}

[1]. Janssen I, Katzmarzyk PT, Ross R. Body Mass Index, Waist Circumference, and Health Risk. Arch Intern Med. 2002; 162:2074 - 2079.

[2]. World Health Organization. Medical center: Obesity and overweight [Internet]. 2011 [update 2011 Marc; cited 2016 Oct 10]. Available from: http://www.who.int/mediacentre/factshee ts/fs311/en/

[3]. Ogden CL, Yanovski SZ, Carroll MD, Flegal KM. The Epidemiology of
Obesity. Gastroenterology. 2007 May;132(6):2087-102.

[4]. Cheung B, Li C. Diabetes, and Hypertension: Is There a Common Metabolic Pathways? Currents Atherosclerosis Reports. 2012;12(2):1606.

[5]. Choices NHS. Obesity - NHS Choices [Internet]. 2013 [cited 2016 Nov 25]. Available from: http://www.nhs.uk/Conditions/Obesity/Pa ges/Introduction.aspx

[6]. Bray GA. Obesity is a chronic, relapsing neurochemical disease. Int $\mathbf{J}$ Obes Relat Metab Disord 2004; 28(1):34-38.

[7]. Despres JP. Intra-abdominal obesity: an untreated risk factor for type 2 diabetes and cardiovascular disease. J Endocrinol Invest 2006; 29(3 suppl):77-82.

[8]. Bastard JP, Maachi M, Lagathu C, et al. Recent advances in the relationship between obesity, inflammation, and insulin resistance. Eur Cytokine Netw 2006; 17(1):4-12.

[9]. World Heart Federation. Obesity [Internet]. 2013 [update 2013; cited 2016 Oct 11]. Available from: http://www.world-heartfederation.org/cardiovascularhealth/cardiovascular-disease-riskfactors/obesity/

[10].Bray GA, Bouchard C. Handbook of Obesity: Clinical Applications Third Edition. New York; Informa Healthcare USA, Inc: 2008.

[11].Logue J, Thompson L, Romanes F, Wilson DC, Thompson J, Sattar N, et al. Management of obesity: summary of SIGN guideline. BMJ. 2010 Feb 24;340(feb24 2):c154-c154.

[12].Dahlan SM. Besar sample dan cara pengambilan sampel. Penerbit Salemba Medika. Jakarta. 2010.

[13].Martire LM, Schulz R. Involving Family in Psychosocial Interventions for Chronic Illness Association for Psychological Science. 2007; 16(2): 90 - 94. 